\title{
Vilija Targamadze
}

Vilnius University (Lithuania)

\section{Mariam Manjgaladze}

Caucasus University (Georgia)

\section{A Good General Education School for the New Generation: Illusion or Reality}

\begin{abstract}
The $21^{\text {st }}$ century poses challenges to the general education school, which not only has to respond to the needs of education, culture, national and global context and others but also to focus on the new generation possessing specific features. The question arises: Can the new general education school be created for the new generation? If yes, what aspects of its development should be evaluated? The aim of the article is to highlight the aspects in the design of the good general education school creation. It studies the new generation in terms of their characteristics and the Conception of Good School (2015), which can become a map designing the school for the new generation. Highlighting the essence of this conception, it is emphasised that "The Good School is the one that is built on underlying humanistic values, strives for the success of discovery and personal development, and follows the school community's agreements and learning in its activities"(Geros mokyklos koncepcija, 2015: p.1). The possible school models can also be analysed.

Undoubtedly, the school model can be different, linking formal and non-formal education, the real and virtual environments. Moreover, it is possible to construct various activities on the basis of community agreements, to employ various forms, methods and ways of education, even to modify the curriculum but it is even more important to ensure the child-centred education, which allows responding to children's needs and interests and observing their compatibility with those of society. The gap between the real and the virtual spaces should be avoided and their possibilities and potential for improvement of children's education should be fully used.
\end{abstract}

Kay words: General Educations, New Generation, School Model

\section{Introduction}

The world has been undergoing changes: globalisation processes have not only resulted in transformations in economy, education, culture and other spheres of life but also have stimulated rapid advancement of technologies. Therefore, the observation of M.A Peters, 
P. Jandric sounds rather convincingly: "In the context of today's 'bio-informational capitalism', challenges from early days of digital technologies become even larger and more important. For instance, there is no doubt that the struggle between the ethos of free sharing characteristic for early days of computing, and its later appropriation by large capital which created some of the richest corporations in the world, has profound consequences to development of informational capitalism. In the context of bioinformational capitalism, the question of owning code translates into the question of owning the blueprint of life"(Peters, Jandric, 2019: p. 976). Without any doubts, if 'bio-informational capitalism' consolidates its position in society, it will have impact on social development all over the world. Already now, the artificial intelligence influences teaching/learning but this has not been properly employed so far. It is necessary to acknowledge that the majority of schools are still trapped in the clutches of the last century: "the school has remained conservative and 'text-based' over centuries; moreover, a child with non- textual thinking and world view has always been regarded as a misfit in the traditional school system and even a lagging behind learner" (Lombina and Yurchenko, 2018, p. 1).

Meanwhile, the new generation $\mathrm{Z}$ and the representatives of generation $A$, who have been attending kindergartens and primary schools in most countries, are different and, having assessed their individuality and having made common decisions over educational outcomes, it is necessary to think over the cornerstones in education as well as the model of general education school, its activity and to find ways how to help teachers and children to choose suitable activities.

The observation of P. Jandrić and all (Jandrić et al., 2018) is also attentionworthy: "Haraway's early insights in post humanism, and we know that homo sapiens are simultaneously experiencing evolution and enhancement and that these developments take place within the post digital blurred and messy relationships between physics and biology, old and new media, humanism and post humanism, knowledge 
capitalism and bio-informational capitalism“ (Jandrić et al., 2018: p. 896).

In fact, the problem of striving for the model of good general education school is not new. The search for alternatives became particularly intensive in the periods, which were critical to the general education school. This was observed in the first half of the $19^{\text {th }}$ century, at the end of the $20^{\text {th }}$ century and in the beginning of the $21^{\text {st }}$ century. (Targamadzè, 2010).

The thought of V. Targamadze is also worth attention: "It is a paradox but very frequently forecasting a specific impact of education on one or another individual is complicated, even though education is determined (each country has certain standards, legislation, etc.). Regrettably, education is considerably different today and its effect on a particular individual is even more difficult to forecast than before. It is possible to model one or another scheme of education effectiveness on an individual, organisation, society and others but the flows of education in the virtual and non-virtual space are so powerful that this causes the problem of synergic effect in the individual's education." Today this problem is even more acute because the general education school is still in the trap of the past. Attempts of some schools to escape this stagnation are frequently impeded by bureaucracy. Being slightly more penetrating and flexible, the sector of non-state schools tends to model their process of education answering the realities of the $21^{\text {st }}$ century.

The question is encountered: Is it possible to create a new general education school for the new generation? If yes, what aspects of its creation should be considered?

Moreover, one more question can be formulated: What is the novelty of this article? Through the example of Lithuania, one of the possible conceptual models of school that focuses on the educational needs of the new generation in the $21^{\text {st }}$ century is provided. Therefore, the article presents the essential features of the new generation as well as the insights into the Good School Conception (2015), which are undoubtedly linked with the challenges of the $21^{\text {st }}$ century. 
The aim of the article is to highlight the aspects of the model for creation of good general education school.

The article ontology is based on the beliefs of social constructivism, according to which, human beings construct their personal understanding, which is not the mirror of their acquired knowledge, but it is the result of their personal perceptions, experiences and reflections, when the knowledge and the meanings are constructed from personal experiences, from relationships between people, things and events (Kukla, 2000: p. 6)

The object of the article: a model/sketch for creation of good general education school in terms of aspects essential to the new generation.

The research methods: analysis of scholarly literature and previous research, modelling.

The theoretical significance of the article lies in highlighting the essential aspects in the sketch/model for creation of Good School. The article is relevant from the practical perspective: the identified aspects in creation of general education school can be also adapted to the national context.
An insight into characteristic features of the new generations.

The western sociologists tend to identify emergence of the new generation $\mathrm{Z}$ with introduction of information technologies (McCrindle, Wolfinger, 2010). Immediately, it is appropriate to emphasise that "Millennials enjoy utilizing technology. The Millennial generation became dependent on technology at an earlier age than other generations“( Smith, Nichols, 2015: p. 40).

As early as 2013 Chr. Scholz provided a number of characteristics of generation $\mathrm{Z}$ in his concept of four generations. Table 1 presents four generations, such as Baby Boomers, generations $\mathrm{X}, \mathrm{Y}$ and $\mathrm{Z}$, characterising them according to 8 features: their attitudes (philosophical trend), the prevailing feature, engagement / participation, role and level of activity, volume of knowledge / information, qualification and orientations. Generation $\mathrm{Z}$ is said to focus on pragmatism. It is also characterised as "frivolous" and participating in the global society, their performed role is linked to individualism. Their level of activity is 
high, the volume of knowledge / information is strong, learning is exclusively for yourself and the main orientation is towards personal needs and privacy (separated from profession). These characteristics substantially differ from the features of generations $\mathrm{Y}$ or $\mathrm{X}$. The philosophical trend requires particular attention: realism is typical of generation $\mathrm{Z}$, generation $\mathrm{Y}$ is linked to optimism, scepticism is associated with generation $\mathrm{X}$ and Baby Boomers are regarded to be idealists. The characteristic features of each generation reveal themselves accordingly. It is obvious that generation $Z$ possesses specific characteristics, which will be briefly highlighted further. They cannot be seen as a comprehensive characteristic of generation $\mathrm{Z}$ but more as some strokes of this characteristic.

Table 1: The concept of four generations (Scholz, 2013: p. 1)

\begin{tabular}{|l|l|l|l|l|}
\hline & Baby Boomer & Generation X & Generation Y & Generation Z \\
\hline Date of birth & Starting with 1950 & Starting with 1965 & Starting with & Starting with 1995 \\
& & & 1980 & \\
\hline Approach & Idealism & Scepticism & Optimism & Realism \\
\hline Key features & Self-regulation & Lack of prospects & Motivation & "Frivolous" \\
\hline Engagement/partici & Local community & Local community & International & Global society \\
pation & & & society & \\
\hline Role & Collectivism & Individualism & Collectivism & Individualism \\
\hline Level of activity & Average & Low & Average & High \\
\hline Volume of & Average & Small & Average & Strong \\
knowledge & & & & \\
\hline /information & & & & \\
\hline
\end{tabular}




\begin{tabular}{|c|c|c|c|c|}
\hline Qualification & $\begin{array}{l}\text { Learning for } \\
\text { business }\end{array}$ & Little of learning & Paid education & $\begin{array}{l}\text { Learning } \\
\text { exclusively for } \\
\text { yourself }\end{array}$ \\
\hline Orientations & Only profession & $\begin{array}{l}\text { Personal } \\
\text { needs/privacy } \\
\text { (regardless of } \\
\text { profession) }\end{array}$ & $\begin{array}{l}\text { Profession } \\
\text { related to } \\
\text { personal } \\
\text { needs/privacy }\end{array}$ & $\begin{array}{l}\text { Personal } \\
\text { needs/privacy (aside } \\
\text { from profession) }\end{array}$ \\
\hline
\end{tabular}

Characterising generation Z, G. Soldatova, J. Zotova, M. Lebesheva, V. Shliapnikov (2013: p. 8) state that globalisation process, development of information technologies, mobile connection, internet and other virtual environments have influence on establishment and formation of values among representatives of this generation. A particular attention in this context should be directed to the observation of O. Schneck (2010: p. 3), who claims that education without values is worth nothing and that values do not emerge naturally. It should be admitted that to the biggest extent it is the virtual space that also contributes to formation of the new generation's values. This statement has been substantiated by the research and their results are available in the scientific study “ The New (Z) Generation
- Lost or Undiscovered Yet? Identification of Essential Aspects of New (Z) Generations Child's Learning Processes “(Targamadzè V. et all, 2015). The study also provides for various characteristics attributed to the new generation: hyperactivity; lack of skills to analyse and generalize information and to link it with the context; loop reading, which is replacing linear reading; setting goals and ways of their achievement; a big number of generation $\mathrm{Z}$ individuals possess too high self-confidence, which is not fully adequate to their abilities; fast search for information in the virtual space; curiosity and other features. Being digital natives, they frequently mix the real and the virtual worlds and tend to transfer the norms and rules from the virtual space and the social networks, in particular, to the real one. Therefore, as it 
can be seen from the qualitative research conducted in 2019, which aimed to identify the opinion of generation $\mathrm{Z}$ teachers about their generation $\mathrm{Z}$ learners (12-14 year old teenagers), they mostly communicate in the virtual environment. For this reason their communication in the real world is getting weaker and they lack real life communication skills.

In fact, this does not reflect all the qualities of the whole new generation and they have to be regarded as possible because the features can be very individual. There are representative of this generation, who spend little time in the virtual space and the ones, who nearly live there and browse all the time.

Defining the features of Good School. Lithuania prepared the Conception of Good School in 2013 and approved it in 2015. It should be noted that the workgroup of this conception encountered difficulties defining what Good School is. And this is understandable because construction and presentation of definition is a complex process. Finally, it was decided to define the Good School as follows: "The Good
School is the one that is built on underlying humanistic values, strives for the success of discovery and personal development, and follows the school community's agreements and learning in its activities." (Geros mokyklos koncepcija, 2015: p. 1).

Such definition of Good School determines the main values of the Conception and provides for the direction while improving school activities: orientation to humanistic values and social constructivism as it is clear that each person sees the world individually and constructs it individually as well. Therefore, it is important to rely on community's agreements. The striving for purpose, discovery and success was introduced considering the new generation: they find it important to see their meaningful activity, to discover (a very curious generation) and to experience success. This definition serves as foundation, which simultaneously indicates orientations for activity. And the orientations are enhanced by the aspects of the Good School in the Conception of Good School (2015: p. 4-7): 
13.1. Personality growth. It is characterised by the following features: personality maturity (self-perception, self-value, value-based orientations and lifestyle); achievements (a whole of general and subject-specific competences acquired by a learner); progress (the level achieved during a certain period of time, taking into account the learning start and possibilities of personal development, optimal pace for a learner and requirements provided for in the general curricular). The main and intended results of school activities: maturity of learners' personality, educational outcomes that comply with individual potential and continuous educational progress.

13.2. Life at school: self-expressive participation. It is characterised by the following features: activities, events, adventures (extracurricular clubs, organisations, projects; campaigns, entertainment and other events); learners' well-being (to feel accepted, respected, safe, to enjoy being at school and consider this being meaningful); sense of community (membership, unity, sharing, care for others, support, obligations); self-control (consulting, initiation, making and implementation of solutions, creation of school life). Selfexpressive participation in school life is as important for personality growth as formal education. In the Good School life and education merge, activities and spaces for them, life organisation and experiences intermingle as well.

13.3. Self-education (learning): interactive (dialogue-based) and exploring. It is characterised as: interesting and growing (surprising, provoking, creating challenges, sufficiently broad, deep and optimally complex); open and experiential (grounded on doubt, research, experimenting and creation, right to make mistakes, to find own mistakes and to correct them); personalised and selfdirected (based on personal needs and questions, choice of learning objectives, pace, ways, sources and partners, selfobservation and self-assessment); interactive (based on interaction and partnership, friendly, communal, network, crossing school borders (global); contextual, relevant (educating various competences necessary for contemporary 
life, related to life experience while preparing for solving real world problems, using the variety sources and information technologies). School students learn to solve life-related problems and develop competences that are relevant in contemporary life. They learn exploring, experimenting, discovering and inventing, creating and communicating. Self-education (learning) is built on dialogue (learnerslearners, learners-teachers, learners external partners), on information received during this dialogue as well as on emerging ideas and created meanings. It is transferred outside school and becomes lifestyle as it continues at home, among friends and in non-formal education institutions. It occurs engaging in social networks and using other modern technologies.

13.4. Education (teaching): supporting self-education (learning). It is defined as: targeted (choice of educational goals and ways, planning of education grounded on learning school students and their observation, reflection and evaluation of (self-)education); different for different learners (considering differences in learning needs, choices, possibilities, styles and putting forward various and appropriate possibilities of learning pace, ways and techniques); flexible (applying various models for designing educational plans, grouping of people, use of time and school spaces and other resources); partnership-based. Education (teaching) in the Good School is not a goal in itself and helps learners to develop various competences that are of importance to them and society, teaches them flexibility in changing situations and ability to cope with challenges, encourages learners to raise questions and to think.

13.5. Personnel: diversity of personalities. They are characterised using the following features: positiveness of attitudes (self-values; belief, trust in and care for learners; working motivation - an interest in own subject and work at school, enthusiasm); professionalism (knowledge of subject, possession of competences necessary for profession and wisdom); personal development (selfobservation, learning, openness to new 
experiences, mobility); a balanced team (diversity of personalities and complementing each other, different age groups of teachers, succession of generations). The school is as interesting and diverse as different are people working there: men and women of various age, possessing different competences and life experience, acknowledging different educational styles and interesting personalities. All the teachers working at school are characterised by positiveness of attitudes, i.e. high self-esteem, trust and care for learners, high motivation for work, sincere interest in the study subject taught and civic responsibility.

13.6. School community: a learning organisation. Its main features are: learning with others and from others (community learning - working with colleagues, sharing experience, discoveries, ideas and works, observing lessons of colleagues, studying various sources together with colleagues, learning from learners); solidarity (formation of groups consisting of teachers and other staff members with shared functions, helping each other and striving for common professional goals); reflexivity (discussions of school community, reflection on activities, self-assessment, agreements regarding future based on the results of the aforesaid activities and planning); promotion of learning and professional improvement (stimuli for professional development and system of its organisation), openness of organisation to the world (partnership, joint projects, engagement of graduates, networking, etc.). School community is gathered together in a lifelong learning organisation.

13.7. Leadership and management: empowering. They are defined as: a clear, uniting and inspiring vision (well-known to everybody, acceptable, based on humanistic values); culture of dialogues and agreements (participation of all the members of school community in decision making); shared leadership (based on trust, obligation and empowerment, management culture that encourages initiative-taking and assuming responsibility); efficient administration (transparent, simple, not overburdening, convenient administration, efficient distribution of 
resources and their economical use); creativity and volition to act (creation of ideas, experimenting, courage to take risk, to take difficult decisions and persistence while implementing them). Schools encourage empowering leadership. The school vision and strategy are created by the school community and they are clear and inspiring.

13.8. Educational environment: dynamic, open and functional. It is characterised in the following way: 'classrooms without borders' (convenient multifunctional and easily transformed, varied use of school premises, 'outdoor classrooms' and other adjustments of school territory to education); environment that stimulates education (books, variety of details and equipment, functional and original furniture, colours, materials, lighting, plants, sounds, fragrances, convenient (dis)order, etc.); learners' contribution to creation of environment (implemented school students' ideas and projects, their works, and things in the environment); virtual environment (school internet website, variety of its content and ways of accessing it, its liveliness and popularity).

Open educational environment: from traditional classrooms to ones 'without borders'.

13.9. Local community and an institution with the rights and obligations of school owner, acting as an establisher, meetings of participants (an owner): committed. Their features: strategizing (creating the vision of education, foreseeing goals, assuming responsibility for their implementation); encouraging (applying educational and formative assessment, combining forms of 'strict' and 'soft' assessment, allowing for speaking out problems and helping to cope with them, encouraging school initiatives); supporting and trusting (clearly foreseeing and allocating sufficient resources, creating favourable environment for collaboration with various partners, supporting schools through various formalised support services). An institution with the rights and obligations of school owner, acting as an establisher, and a meeting of participants (an owner) are committed and supportive to the school. The school 
vision and strategy are created by school personnel, learners and their parents, local community, an institution with the rights and obligations of school owner, acting as an establisher, and a meeting of participants (an owner) assume responsibility for implementation of goals. The school is trusted, it functions independently and accounts for agreed results in accordance with procedures provided for by laws.

All the aspects listed in the Conception of Good School are equally important. They are as if orientations in its activity while orienting its activity to the interaction between an individual and school community. Formulating the mission, vision and goals of school and implementing them. A considerable attention is also allocated to the interaction with the local community. It is understandable because the school life is an organic phenomenon and it has to be created together.

The scheme of Good School (Picture 1) reflects it essential components, which have to be considered in their activity. In particular, a specific attention should paid to student experiences and educational outcomes placed on the Scales of Themis. This is a new approach in Lithuania but it is relevant because the school life and its experience is unique and more or less significant for each learner, whereas educational outcomes are not only ordinary achievements (academic in particular) but also his/her maturity and progress.

The indicated scheme clearly distinguishes two parts: the school mission and the factors that influence the implementation of the mission. The scheme provides for the main elements of each part. They all have to be interrelated and respond to the definition of school, which encodes its foundation and the aforesaid school aspects. In general, the Conception of Good School has to be approached as a map for directions. This conception is not strictly regulating. On the contrary, it calls for creation and revelation of uniqueness of school life. 


\section{Picture 1}

\section{GOOD SCHOOL PATTERN SCHEME}

Ministry of Education and Science of the Republic of Lithuania, 21 December 2015 No. V-1308

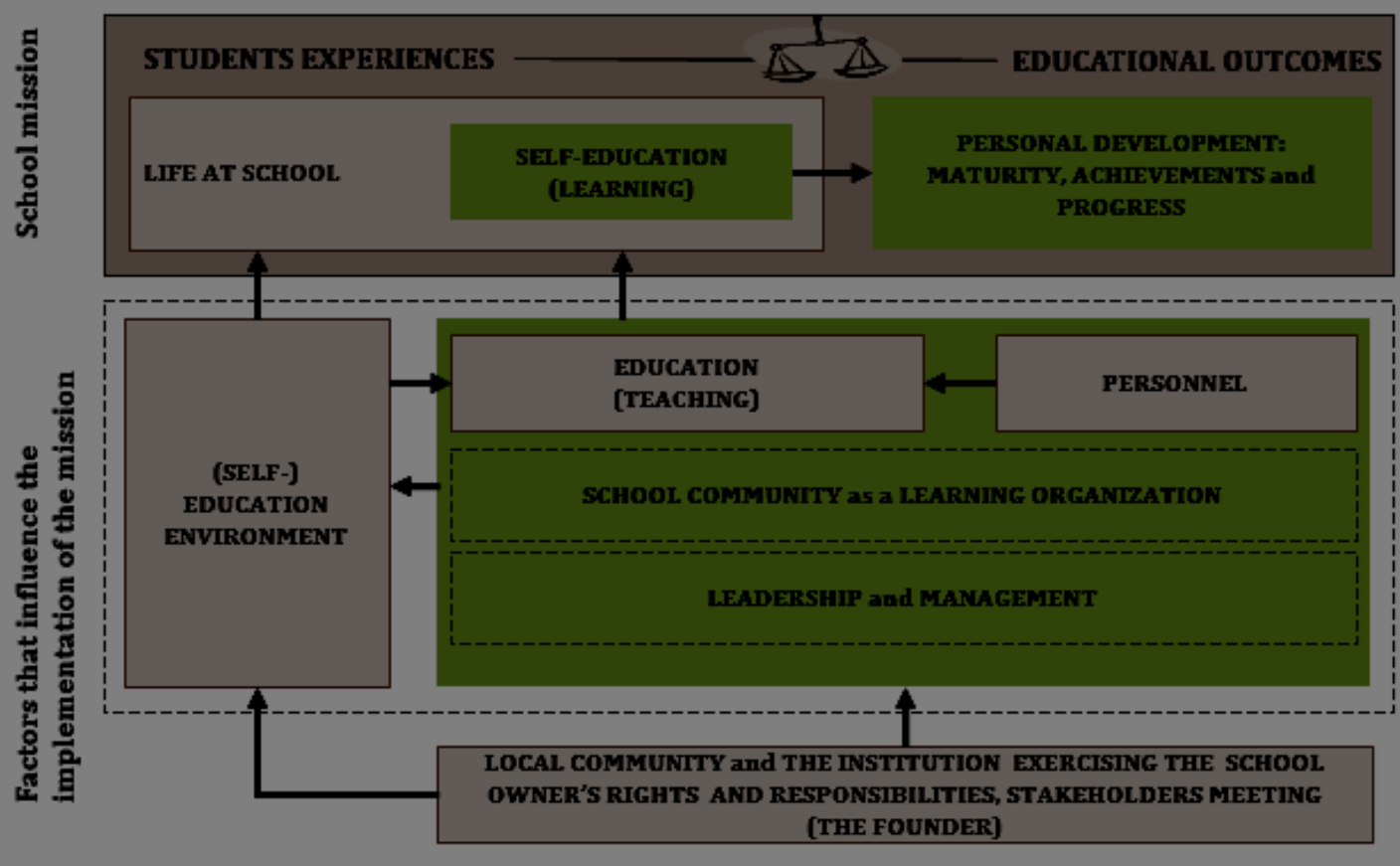

\section{Discussion}

The new generation is specific and this should be considered while creating the new school for this generation. The Conception of Good School was created taking into account the essential features of this generation. Moreover, the flexibility of this conception allows for various education models. However, generation Alpha follows generation Z and the representatives of the former have even stronger attachment to the virtual environment (not all of them, of course). Artificial intelligence has been strengthening its position, the Fourth Industrial Revolution has been continuing, the tendencies of globalisation have been strengthening, etc. The following question emerges: Is school as such necessary at all? Perhaps it is possible to move all the learning into the virtual space, where the demand for learning has been continuously increasing. The question is relevant 
because representatives of the new generation ( $Z$ and Alpha) are rather attached to the virtual environment and satisfaction of their inclinations could perhaps strengthen their learning motivation. Then at least two questions can be asked: Are teachers (tutors or mentors) ready for it? And would not this even increase the gap between the generation $\mathrm{Z}$ children and young people and the real environment? As it can be concluded from the qualitative research, which aimed at identifying modus vivendi of generation $\mathrm{Z}$ teenagers (13-14 years olds) as viewed by generation $\mathrm{Z}$ teachers (Targamadzè, 2019), the generation $\mathrm{Z}$ lacks competences for communication and collaboration in the real environment, tends to transfer the norms and rules of online communication to the real world and others. Therefore, their even bigger concentration on the virtual environment would contribute to an even bigger alienation from the real environment. The preparation of teachers to work with the new generation is also problematic because the new generation is hardly known to them (Targamadzè and all, 2015).
Considering the school models, it is necessary to remember the three possible school scenarios, which are discussed by the author of this article in "General Education School: Process of Eutrophication) (Targamadzè, 2019). The models were originally presented by $\mathrm{M}$. Newby as early as 2005. They are presented as follows:

- Scenario 1: education everywhere ("Schools fell into disrepute in the early decades of the twenty-first century because they could not adequately tailor-make learning experiences for each child individually and were failing to prepare people for a knowledge economy. School became deinstitutionalised and in most cases dismantled, the buildings often used for other things.") (Newby, 2005: 255-256);

- Scenario 2: gifts, actually ("In fact, this became a part of their mission. Yes-schools, at least, were still places to which people went to be together for a purpose, and a good purpose, too! And as schools began to recognise that they could, in 
some way, advocate the virtues and benefits of collaboration and the group rather than (or perhaps as well as) individualism and personal enterprise, they began to succeed in unexpected ways. Parents began to feel the loss of something, and started to recognise the school as the place where they might recover it. Thus encouraged, schools went out and won back their constituencies, and they did it by offering to become the most effective bulwark against social fragmentation and a values crisis.") (Newby, 2005: p.258);

- Scenario 3: the education marketplace( Increasingly, however, some smaller producers are looking vulnerable these days, and we are beginning to see stupendously good Edusoft programmes which are being used in schools in many different countries. Multinational companies can, of course, bring massive resources to making these wonderful products. From the pupil's perspective, each learning event seems made for them alone and works at their own pace, though in fact individualised versions of the same product are being sold all over the globe and being used by millions of pupils.") (Newby, 2005: p. 260).

Having presented the scenarios, there firstly emerges a desire not to focus on extremes and to present a different scenario, which would respond to the tendencies of the $21^{\text {st }}$ century as well as challenges faced by every country. Surely, in the beginning this would be an alternative school or an institution to a usual one. Self-directed learning can be constructed in a general education school offering them to independently design a navigation system for attainment of educational outcomes. To ensure functioning of such system, learning packages for school students should be prepared and the aims have to be agreed upon but a schoolchild can study the selected topics and at his/her own pace, etc. Certain control elements have to be introduced as well: deadlines for completing one or another assignment, self-assessment and feedback on the 
studied course. Lessons would not be organised in such a school, learners would study in groups or according to their achievement levels and the teachers would become mentors, assistants or would help their learners in other ways. It is obvious that each school would have to model a flexible process of education, which is based on the paradigm of learning. Moderate use of virtual or distant learning would also be welcomed. In other words, each school would model the process of education taking into account the needs and interests of their learners aiming at relevant standards of education (these are usually state standards). The responsibility for ensuring the learners' achievement of certain standards would be assumed by the school and the teacher (mentor, tutor or facilitator). Taking into account the fact that the number of special needs children have been growing lately, education has to be more personalised and specialists in educational support have to be addressed as well (Diržytè, A., Mikulènaitė, L., Kalvaitis, A.,2016).

In any case, this does not contradict the conception of Good School (2015), which is only presented as a map for creating a good school but it is necessary to understand it and be able to use it creating a navigation system for activities in own school. However, the question still remains open: Can it be done focusing on the holistic approach to education, implementation of the learning paradigm and other challenges, problems and possible solutions related to school creation?

\section{Conclusions}

- Seeking to respond to the $21^{\text {st }}$ century challenges, it is necessary to construct the model of general education school, which would establish possibilities for flexible modelling of education at school, when the school, the teacher, the learner and parents (or caregivers) assume responsibility for educational outcomes, which should not be perceived as academic achievements only. The understanding of educational outcomes should include the maturity of a learner, his/her progress, achievements and the activities of school should be 
projected on the basis of community's agreement.

- Alternative education, alternative training and alternative school in every society acquire their own meaning and their narrative in certain texts and contexts emphasises specific meanings and essences. Sometimes missions delegated to an alternative school may significantly differ due to the merging of the concept of alternative training and/or alternative education or its specification in different methodological contexts. In any case, alternative education should be understood as a constructive interaction among people, which aims at attainment of goal. This is also linked to cultural treasures because culture and education are two interacting sands. Alternative education in the aforesaid relation would acquire synergy, which can have both positive and negative influence on formulation of educational goals and their implementation. This would depend on the understanding of philosophy and mission, on the model and its implementation in each school.

- The model of school can be of different nature: it can combine formal and non-formal education, the real and the virtual environments. Various activities can be built on community's agreements, various forms, methods and ways of education can be employed. It is even possible to modify curricular but above all it is important to ensure child-centred education, which addresses children's needs and interests and is in line with the needs and interests of society. It is necessary to avoid the gap between the real and the virtual spaces and to use their possibilities for improvement of children's education. 


\section{REFERENCES}

Diržytė, Mikulėnaitė, Kalvaitis, 2016 - Diržytė, A., Mikulėnaitė, L., Kalvaitis, A. Autizmo sutrikimų turinčių vaikų situacija ir ị švietimo sistemą galimybės [accessed 0804 2019]. Available online at:

https:/duomenys.ugdome.lt/saugykla/Metodine_medziaga/2017/Dalykai/ Specialioji_pedagogika/Analize_201612.pdf

Falschlehner, 2014 - Falschlehner, G. Die Digitale generation. Jugendliche lesen anders. Wiena: Verlag Carl Ueberreuter. 2014.

Jandrić, Knox, Besley, Ryberg, Suoranta, Hayes, 2018 - Jandrić, P., Knox, J., Besley, T., Ryberg, T., Suoranta, J., \& Hayes, S. Postdigital Science and Education. Educational Philosophy and Theory, 50 (10) 2018; doi:10.1080/00131857.2018.1454000 [Taylor \& Francis Online], [Web of Science ${ }^{\circledR}$ ], [Google Scholar]Geros mokyklos koncepcija, approved by the

Minister of Education and Science of RL, 21 December 2015, No. V-1308

Vilnius. Available online at: https://www.e-tar.lt/portal/lt/legalAct/f2f65120a 7bb11e5be7fbe3f919a1ebe

Kukla, 2000 - Kukla, A. Social Constructivism and the Philosophy of Science. New York: Routledge, 2000

Lombina,Yurchenko, 2018 - Lombina,T., Yurchenko, О. “Особенности обучения детей с клиповым мышлением“ // Общество: социология, психология, педагогика. 2018.

№ 1, 45-50. DOI: https://doi.org/10.24158/spp.2018.1.7

McCrindle, Wolfinger, 2010 - McCrindle, M., Wolfinger, E. The ABC of XYZ:

Understanding the Global Generation. Australia: University of New South Wales Press Ltd. 2010.

Newby, 2005 - Newby, M. Looking to the Future. Journal of Education for Teaching, 31(4), 253-261, 2005 
OECD, 2018 - The Future of Education and Skills. Education 2030. Available online at: https://www.oecd.org/education/2030/E2030\%20Position\%20Paper\%20(05.04.2 018).pdf

Peters, Jandric, 2019 - Peters, M.A., Jandric, P. Posthumanism, open ontologies bio digital becoming: Response to Luciano Floridi`s Online Manifesto, Education Philosophy Theory/Educational Philosophy and TheoryVolume 51, 2019, Issue 10, https://www.tandfonline.com/doi/full/10.1080/00131857.2018.1551835? scroll=top\&needAccess=true

Schneck, 2010 - Schneck, O. Die neue Generation Y als Herausforderung für die Diversity - Strategie an Hochschulen. Reutlingen: Reutlingen University, 2010

Soldatova, Zotova, Lebesheva, Shliapnikov, 2013 - Солдатова, Г., Зотова, Е., Лебешева, М., Шляпников В. Интернет: возможности, компетенции, безопасность. [The Internet: Possibilities, Competences, Security] Москва: Фонд Развития Интернет ФГАУ «Федеральный институт развития образования» Министерства образования и науки РФ Факультет психологии МГУ имени М.В. Ломоносова, 2013

Scholz, 2013 - Scholz, Chr. Generation Z: Willkommen in der Arbeitswelt.-[Available online at: http://download.sap.com/germany/download.epd?context=15CBA4EB14F95426 F543A9AFDAC5A08074271854ABCEA849F751EBD4813127056BC5C350BE08 3373D1BADEEC6CDCA5C60818EA003CF85895 [accessed: 3005 2014]

Smith, Nichols, 2015 - Smith, T. J., Nichols, T. Understanding the Millennial Generation// Journal of Business Diversity Vol. 15(1) 2015 https://www.researchgate.net/publication/324922926_Understanding_the_Mill ennial_Generation

Targamadzè, 2010 - Targamadzè, V. Alternatyvi bendrojo lavinimo mokykla: mokyklos naratyvo kontūrai. Vilnius: Vilniaus universiteto leidykla, 2010 Targamadzė et all, 2015 - Targamadzė V., Girdzijauskienè, S. et all. [Scientific study]. Naujoji (Z) karta - prarastoji ar dar neatrastoji?: naujosios (Z) kartos vaiko 
mokymosi procesų esminių aspektų identifikavimas. - Šiauliai: Titnagas. - P. 726, - 120 p. - ISBN 978-9955-613-91-6, 2015.

Targamadzè, 2019¹ - Targamadzè, V. Z kartos (13-14 m.) modus vivendi Z kartos mokytojų požiūriu [manuscript]

Targamadzè, $2019^{2}$-Targamadzè, V. General Education School: Process of Eutrophication.Socialinis ugdymas Socialinès klasterizacijos prielaidos / Assumptions of Social Clustering 2019, Vol. 51, No. 2. Kaunas: Vytauto Didžiojo universitetas, 2019. 